\title{
Does European Integration Increase Sub-National Power? Evidence from a Time- Series Cross-Sectional Analysis
}

Jana Gómez Díaz and Abelardo Gómez Díaz ${ }^{\mathrm{b}^{*}}$

${ }^{\mathrm{a} D e u t s c h e r ~ B u n d e s t a g}$

Email: janagomezdiaz@gmail.com

b*Universitat Pompeu Fabra

Department of Political and Social Sciences

Carrer de Ramon Trias Fargas, 25-27 (20.199)

Barcelona 08005

Email: abelardo.gomez@upf.edu

*corresponding author

\begin{abstract}
The literature on the relationship between European Union (EU) integration and regional power has produced two opposing theoretical models. Depending on the model, EU integration leads to either an increase or decrease in regional power. Evidence for both, however, has been largely inconclusive, and mostly derived from qualitative case studies. This paper, on the other hand, offers a quantitative, large- $\mathrm{N}$ analysis, using data from fiftysix countries between 1960 and 2010. Its random effects model shows that EU membership
\end{abstract}


considerably increases regional authority within member states over time; and its comparison with another international organization suggests that the effect is not idiosyncratic. Additionally, this paper finds support for two possible mechanisms: the establishment of the subsidiarity principle, and the Commission's requirement to create regional government structures.

Keywords European integration $\bullet$ regional power $\bullet$ self-rule $\bullet$ shared rule.

\section{Introduction}

To what extend does European integration affect regional power? It is a popular question in European studies that has, to date, produced two major opposing theoretical models: the multi-level governance model (see Marks 1993; Caporaso and Keeler 1993; Hooghe and Marks 2001; Marks and Hooghe 2004; Stephenson 2013) and the state-centric governance model (see Hoffmann 1966, 1982; Taylor 1983; Moravcsik 1991, 1993; Garrett and Weingast 1991; Garrett 1992; Milward 1992; Caporaso and Keeler 1993; Streeck 1996; Marks et al. 1996). The former argues that, in the course of European Union (EU) integration, nationstates are weakened by the transfer of their powers to the supra-national and sub-national levels. In other words, it views EU governance as one of intertwined political arenas with shared competences. The latter, on the other hand, submits that nation-states are still the most powerful actors - unsurpassed by the supra-national and sub-national levels.

While there is substantial evidential support for both models, it mostly derives from qualitative case studies that use one or multiple EU countries; as well as from (mostly) normative descriptions of extra-state channels of sub-national influence (see Jeffery 1997; 
Tatham 2018; Huwyler et al. 2018). This paper, however, offers a quantitative approach that may serve to expand the external validity of such work. It does not focus on any specific, potentially-varying access points available to regions, but instead adopts a more holistic approach. It looks directly at regional competency gains during EU integration; makes the first attempt at uncovering the causal mechanisms that link EU integration to regional power; and - because the EU's effect on regional power is expected to be idiosyncratic - it compares its effect to that of a comparable international organization.

Concretely, this paper expects EU membership to be positively related to regional authority, and for the two dimensions of power herein considered (i.e., self-rule and shared rule) to expand with increasing integration. It also expects EU integration and regional power to be linked through the following mechanisms: the establishment of the principle of subsidiarity and the requirement for accession candidates to create regional structures. In order to empirically test these expectations, this paper relies on a large-N statistical analysis. The sample includes panel data on international organization membership from twenty-three EU countries and thirty-three non-EU countries between 1960 and 2010, as well as decentralization data from the Regional Authority Index (Hooghe et al. 2016). Furthermore, it relies on a random effects model to test if regional authority is affected by the length of EU membership, while controlling for other causes of decentralization previously considered in the literature.

\section{Literature Review}

To start, it is essential to define what we understand by decentralization. Because it tends to be characterized based on the distribution of power in multi-level systems, this paper relies 
on a combination of two concepts. The first is Elazar's (1987) concept of self-rule and shared rule. ${ }^{1}$ Simply put, the former refers to a sub-national unit's power to make decisions, as well as to finance and implement policies that concern its own territory; and the latter refers to the extent to which a sub-national unit is entitled to co-determine policies that have effects beyond its borders. The second is Brancati's (2006: 654) description of political decentralization as 'a system of government in which there is a vertical division of power among multiple levels of government that have independent decision-making power over at least one issue area'.

It is also important to identify the causes of decentralization. Traditional explanations argue that cleavages - e.g., regional socio-economic differences (Panizza 1999; Wu and Wand 2013), as well as ethnic, linguistic, and religious fragmentation in multi-national states - tend to generate demands for regional self-rule (Jeffrey 1997; Panizza 1999; Amat et al. 2009; Letelier 2016). Other explanations point to the presence of ethno-regional parties (Rokkan and Urwin, 1982); parties with highly decentralized structures (Willis, Garman, and Haggard 1999); democratization processes (Bird and Vaillancourt 1999; Hooghe et al. 2010); large population and area size (Oates 1972; Bahl and Nath 1986; Panizza 1999); as well as functional pressures such as defense and security policies and economic incentives (Besley and Coate 2003; Stegarescu 2009; Hooghe et al. 2010). These explanations, however, mostly refer to internal - and relatively stable - factors within a given country and ignore the considerable variation of regional authority over time (both within and across countries)

\footnotetext{
${ }^{1}$ In this case, he writes about federalism. However, his concepts of self- and shared rule describe a system of vertical distribution of power (as is political decentralization). See also Hooghe et al. (2016).
} 
(Hooghe et al. 2016). It is why some authors link decentralization to external factors, ${ }^{2}$ which center around two major opposing theories: the multi-level and state-centric governance models.

\section{The Multi-Level Governance Model}

The multi-level governance model describes how the supra-national, national, and subnational levels co-exist in a structure of multiple shared competences (see Marks 1993; Marks et al. 1996; Hooghe and Marks 2001; Marks and Hooghe 2004; Stephenson 2013). In this view, nation-states remain powerful, but are nonetheless weakened by EU integration. Simply put, it considers nation-states to no longer have a monopoly over interactions with EU institutions and policy-making structures, because sub-national units are empowered to bypass nation-states and operate directly at the supra-national level (see Keating et al. 2015).

The model also argues that regions benefit greatly from the breakdown of nation-state boundaries and the creation of new arenas for political, social, and economic processes (Hooghe and Marks 2001). The reason is that the new channels for political participation provide regions access to more sources of information, financial resources, ${ }^{3}$ and political legitimacy - not to mention opportunities to increase their levels of expertise and improve their organizational capabilities (Marks et al. 1996).

In terms of evidence, some authors argue that the framework for an EU political order in which competences and sovereignty are shared derive from the Treaty of Maastricht itself

\footnotetext{
${ }^{2}$ For example, the influence of international organizations.

${ }^{3}$ Access to the EU's single market and the expectation of continued membership may reduce the perceived benefits of belonging to the national state (or, put differently, reduce the cost of demanding additional autonomy or secession) (see Hooghe and Marks 2001, 2016; Alesina et al. 2005).
} 
(Bullmann 1997); and that its principles of solidarity, conferred powers, partnerships, subsidiarity $^{4}$, and additionality, actually strengthen regional actors (Hooghe and Keating 1994; Moreno 2001; Margedant 2006; Sturm 2009). Others add that the relationship amongst the Commission, nation-states, and sub-national authorities is not one of hierarchy, but of partnership, as is reflected by their cooperation in the allocation of structural funds (Hooghe and Marks 2001). Another example is the creative margin that regions have in the implementation of EU directives (Margedant 2006; Elias 2008; Sturm 2009). Additional evidence includes the fact that various centralized member states (e.g., in Eastern Europe) created regional political institutions in order to qualify for structural funds (Hooghe et al. 2010; Sturm and Bauer 2010; Saarts 2019); and that EU integration led to the establishment of intra- and extra-state channels that by-pass nation-states and decrease their control over domestic interests (Jeffery 1997).

In a different vein, the Council of Ministers requires unanimous voting in order to ratify treaties (Hooghe and Marks 2001), but sub-national actors have the power to affect these processes and cannot be overruled by nation-states or the EU (see Tatham 2018). Integration has also led to regions developing their own foreign policy competences, and has allowed them to increase their political legitimacy by behaving like states on the world stage (Keating 1993; Dieringer 2010). Additionally, regional access to the supra-national level offers them a place to express their ethno-national complaints, nationalist aspirations, and cultural grievances (Keating 1998; Urwin 1998; van Houten 2003). In fact, regional secession

\footnotetext{
${ }^{4}$ Sharpe (1993) argues that the legislative expansion of the EU undermines national autonomy, and that principle of subsidiarity makes the national level obsolete
} 
movements often view the $\mathrm{EU}$ as an attractive, viable alternative to the nation-state (Bookman 1993; van Houten 2003; Jolly 2015). ${ }^{5}$

To our knowledge, the only quantitative studies that pertain to our issue of interest are Schakel's (2009), Hooghe et al.'s (2016b), and Chacha's (2020). The first, however, suffers from at least two important limitations. First, it does not focus on EU integration as the key explanatory variable; and second, it uses a binary EU membership variable to show that it actually strengthens regional power. This binary coding of EU membership obscures the assessment of the proposed relationship. The second study uses an aggregate variable for supra-national governance; it does not focus on the EU; it does not contrast the EU with another international or territorial organization; and it does not test for possible mechanisms in order to analyze how EU membership is connected to a rise in regional power. And the third takes a different theoretical and argumentative approach; it also relies on a binary variable of EU membership; it does not believe that the EU is comparable to other organizations; and it does not test for the mechanisms considered herein. Therefore, based on the multi-level governance model and the idea of a centrifugal redistribution of power (Jeffery 2000; Hiscox 2003; Kahler and Lake 2003), we hypothesize the following:

H1: EU integration leads to the decentralization of power in member states.

Moreover, because there is still uncertainty about the mechanisms that actually link EU integration to the increase in regional power, we also hypothesize the following:

\footnotetext{
${ }^{5}$ In part, the EU is perceived as a good alternative because it provides a safety net that includes access to financial resources, a bigger market, and an inter-governmental system with established institutions.
} 
H2: EU integration increases regional power through the establishment of the subsidiary principle and the Commission's requirement that accession candidates create regional structures.

\section{The State-Centric Governance Model}

In contrast with the multi-level governance model, the state-centric model views member-states as the central and ultimate decision-makers in the EU (Marks et al. 1996). According to the model, they are the only actors to engage with the supra-national level and concede only limited competences. Supra-national institutions are seen to be controlled by state executives and serve to reach specific policy goals determined by intra-state political bargaining (Marks et al. 1996). Similarly, local actors can only exert influence through traditional channels and cannot - or tend to not - bypass nation-states (see Tatham 2008, 2010).

In terms of evidence, some authors point to the fact that sub-national units go unmentioned in EU treaties as proof that the EU is blind to their interests; and that whatever initial regionalist trend that arose from the Treaty of Maastricht has nonetheless declined considerably (Jeffrey 1997). Others question the apparent alliance between supra-national and sub-national actors, since the Commission only offers careful, unofficial declarations about regional governance (Brusis 2002; Keating 2004). There is also skepticism about the Committee of the Regions, since nation-states select its delegates; it has no hierarchical structure; and it is politically, judicially, and financially weak (Bullmann 1997; Loughlin 1997; Hooghe and Marks 2001; Dieringer 2010; Nagel 2010). Moreover, there are arguments 
against the effectiveness of trans-regional networks, which are not generally involved in long-term projects and lack societal and economic participation (Weyand 1997). At best, the state-centric model thinks of these access points as mere efforts at mobilization, and not palpable influence (Hooghe and Keating 1994; Jeffrey 1997, 2000; Kohler-Koch 1998; Sturm 2009). In fact, more recent studies find that even 'highly autonomous regions' exhibit 'little evidence of bypassing behaviour' (Beyers and Donas,2014). ${ }^{6}$

In order to test these arguments, we do not only look at regional authority as such, but at the two different dimensions of power: shared rule and self-rule. ${ }^{7}$ If we follow statecentric arguments, shared rule should remain stable (or even increase slightly) with EU integration - but self-rule should decrease. To the point, because we are skeptical of statecentrist arguments, we present the following hypothesis:

\section{H3: Both self-rule and shared rule increase with EU integration.}

Ultimately, there has not been any definitive evidence for either model. Some, in fact, argue that whether regions use the EU as a source of political and economic support depends on economic, administrative, societal, and constitutional strength, as well as on varying regional identities and sizes (see Hooghe and Keating 1994; Amin and Tomaney 1995; Keating 1998; Kohler-Koch 1998; Jeffery 2000; Brusis 2002; van Houten 2003; Tatham 2015). In other words, they argue that the influence of EU integration is differential, and not uniform.

\footnotetext{
${ }^{6}$ See also Tatham $(2008,2010)$.

${ }^{7}$ See Chacha (2020) for a similar approach.
} 


\section{The Influence of International Organizations}

So far, we have reviewed the literature that pertains to the EU. However, one could wonder if there is a general trend towards decentralization; if the effect of the EU is idiosyncratic; or if comparable international organizations have a similar effect on decentralization. Fortunately, there is some literature on the effects that international organizations have on decentralization. ${ }^{8}$ Large international cooperation institutions, for example, often push for the creation of regional levels of governance in poorer countries as a condition for development (see Jordana 2001). They argue that decentralization improves the provision of public goods and services to large populations; that it reduces the arbitrariness of the central state; that it fuels economic development; and that it reduces poverty (Jordana,2001; Shah2004; World Bank 2004). To this end, they often fund projects with decentralization strategies; they lend money directly to sub-national governments; and offer seminars and workshops on decentralization to pertinent experts and fiscal authorities (Litvack, Ahmad, and Bird 1999; La Cruz et al. 2010; Brosio 2012). Nevertheless, there is also conflicting evidence. The World Bank, for instance, can simultaneously demand decentralization and centralized economic strategies (Brosio 2012). Therefore, the effects of these types of international organizations require additional testing.

In all, this paper expects the effect of EU integration on decentralization to be an idiosyncratic phenomenon (i.e., that the EU has a particular effect on decentralization that other international organizations lack). In other words, it expects the impact of EU integration

\footnotetext{
${ }^{8}$ Especially when it comes to the World Bank, the Inter-American Development Bank (IDB), and the United Nations' Economic Commission for Latin America and the Caribbean (ECLAC).
} 
on regional power to not be part of a general, world-wide trend towards decentralization, or to exist due to the mere presence of an international organization. For this reason, we also introduce an indicator for World Bank membership in our analysis, as a placebo test. Evidently, the EU is not the same type of international organization as the World Bank, but they are both '[bodies that promote] voluntary cooperation and coordination between or among its members' (McCormick 1999). ${ }^{9}$ In this sense, the EU is an international organization that falls on both inter-governmental and supra-national categories. For this reason, and considering the nature of this paper, we believe that the EU and the World Bank can be adequately compared.

To sum up, the literature shows that, to date, decentralization has been mostly linked to internal country factors, such as heterogeneity, size, and democratization. Additionally, it offers various analyses about the impact that international organizations and EU integration have on the empowerment of the sub-national level; and it describes the mobilization of the sub-national level via extra-state access points, ignoring the consequences of EU integration on regional authority. But perhaps most importantly, it shows that the two main models (i.e., the multi-level governance and state-centric models) have been arduously, yet inconclusively defended using mostly qualitative approaches. The only quantitative exceptions either present important shortcomings or use a different conceptual framework. Herein lies our contribution.

\section{Data}

\footnotetext{
${ }^{9}$ Admittedly, it is but one definition, but there is also no consensus on the matter.
} 
In order to examine the impact of EU integration on decentralization, we use a large-N statistical analysis. It includes data from longitudinal international organization membership; data on decentralization from the Regional Authority Index (Hooghe et al. 2016); democracy levels from the Polity IV index (Marshall et al. 2018); data on heterogeneity from the Alesina et al. (2003) index; scores on party system nationalization from the Constituency-Level Elections Archive (CLEA); and other country-specific data from World Bank sources. In all, our dataset includes fifty-six countries and a total of 1,926 observations ${ }^{10}$ from 1960 to 2010 .

\section{Dependent Variables}

Decentralization has been measured in different ways (see Harguindéguy et al. 2019), but we use the Regional Authority Index (Hooghe et al. 2016). It contains detailed information on decentralization in the form of different self-rule and shared rule dimensions from eightyone democratic or quasi-democratic countries between 1950 and 2010. As mentioned earlier, the variables shared rule and self-rule reflect the different dimensions of regional power.

Shared rule is coded as an additive scale that ranges from 0 to 12 . Its individual values determine the extent to which regional representatives co-determine national legislation; how far regional governments co-determine national policy in intergovernmental meetings; the extent to which regional representatives co-determine the distribution of national tax revenues; how much regional governments co-determine sub-national and national borrowing constraints; as well as the power regional representatives have to co-determine constitutional change (Hooghe et al. 2016). Self-rule, on the other hand, ranges from 0 to 18.

\footnotetext{
${ }^{10}$ Originally, the dataset included eighty-one countries, but it was reduced to fifty-six after eliminating those with missing values on relevant variables.
} 
It includes the depth of administrative institutions in sub-national units; the range of policies for which a regional government is responsible; the extent to which regional government can independently tax its population; how much regional governments can borrow; as well as how independent are regional executives and legislatures (Hooghe et al. 2016).

Finally, regional authority is a continuous variable that is an additive index of shared rule and self-rule, with higher scores meaning more decentralization (per country, by year). Depending on the hypothesis, in one instance we use self-rule and shared rule separately, and in another we use regional authority as an aggregate index.

\section{Independent Variables}

Our key independent variable is EU Membership. It indicates whether, and for how long a state has been a member of the EU. It is coded 0 when a country is not (yet) an EU member; 1 for the accession year; and then takes the number of every year that followed afterwards. This continuous variable - as opposed to the binary variable used by Schakel (2009) and Chacha (2020) - models the effect of having been an EU member for years against new members. Ultimately, the sample includes twenty-three member states and thirty-three non-member states. ${ }^{11}$ In order to compare the effect of EU integration on decentralization to that of another international organization, we include a variable that accounts for World Bank membership. As with EU Membership, it is a continuous variable indicating the number of years. The sample includes countries that are targeted by the two development funds of the

\footnotetext{
${ }^{11}$ The treatment group has 772 observations.
} 
World Bank: the International Development Association and the International Bank for Reconstruction and Development.

\section{Control Variables}

In order to avoid biased results, we include other causes of decentralization previously identified in the literature. Social heterogeneity is one of the most popular explanations of decentralization. It is why ethnic, linguistic, and religious fractionalization is also included in the analysis. ${ }^{12}$ Concretely, we use the widely accepted measure offered by Alesina et al. (2003), which computes the probability that two randomly-drawn individuals from a given country are not from the same ethnic, linguistic, or religious group. The values for this continuous variable fall between 1 for full ethnic fragmentation, and 0 for no ethnic fragmentation. However, we multiply the three aforementioned scores in order to obtain an aggregated index of heterogeneity. ${ }^{13}$

Furthermore, because a highly-nationalized party system is supposed to decrease decentralization, we include a measure of party system nationalization (i.e., the extent to which parties receive similar support across the national territory) (Jones and Mainwaring, 2003). The score is based on the Gini coefficient of inequality in vote shares across constituencies $^{14}$; and the data we use is from the CLEA dataset. We expect this variable to

\footnotetext{
${ }^{12}$ Brancati (2008) shows that these three categories are likely to cause decentralization if they are geographically concentrated.

${ }^{13}$ An alternative is Brancati's (2008) ethno-linguistic concentration index. Nevertheless, it only considers ethnic and linguistic groups - and not, for example, religious ones. Also, the amount of data is limited, as it includes observations until 2000 (and only for at-risk minorities).

${ }^{14}$ The measure was originally introduced by Jones and Mainwaring (2003), but we follow Bochsler's (2010) adjustment. It weighs according to the size of a country's territorial units, and considers a different amount of territorial units across countries.
} 
account for the decentralizing impact of strong non-state-wide parties. Moreover, we include democracy because its levels are said to influence decentralization; it is an EU requirement for accession; and it is likely to affect both the dependent and independent variables. In terms of its operationalization, we use data from Polity IV (Marshall et al. 2018). ${ }^{15}$ We also control for GDP per capita, population size, and surface area, which may affect decentralization, using data from the World Bank. ${ }^{16}$

For the possible mechanisms, we include a binary measure for the Subsidiarity Principle. It is 1 for EU member countries from 1993 onwards (the year the principle was included), and 0 for non-EU countries and the years prior to the Treaty of Maastricht. We also include a dummy variable for the Commission's requirement for accession candidates to create a sub-national level of government. It is coded 1 for the countries that acceded during 2004 and $2007^{17}$, albeit under a single variable. ${ }^{18}$ It also covers the period from 1995 and 1997 onwards, which is when negotiations began, respectively. This is because we expect candidate countries to have begun their decentralization processes before their actual accession, in order to meet the Commission's requirements. Alternatively, the variable is coded 0 for countries that were already member states. ${ }^{19}$

\footnotetext{
${ }^{15}$ It is computed by subtracting the autocracy score from the democracy score. An alternative is to use democracy age instead of democracy level. However, it would probably be highly collinear with the key independent variable, which is also measured in years.

${ }^{16}$ For the sake of simplicity, we divide population by 100,000 and area size by 10,000.

${ }^{17}$ During these Eastern Enlargements, the Commission demanded sub-national structures from accession candidates.

${ }^{18}$ The reason is that the 2007 enlargement only included two countries, which would yield little statistical power on its own.

${ }^{19}$ Non-member states are not included in the sample. This will be further explained in the methodology section.
} 


\section{Method}

This paper uses a longitudinal analysis for both time-specific and country-specific reasons. A simple difference-in-difference comparison amongst member and non-member states would misrepresent the relationship, because EU accession is not expected to have an immediate impact on the internal power structures of member states. It may, however, have an impact in the long-run, which is why we use panel data in a times-series cross-sectional design (TSCS). Moreover, regression coefficients can only be given a causal interpretation when the error term of the structural model is independent of the causal variable of interest. A TSCS design allows us to relax the homogeneity and temporal stability assumption, and offers a reliable basis for causal inference.

Amongst TSCS designs, we argue that a random effects (RE) model is the most appropriate in this case. RE allows us to estimate the effect of both time-variant and timeinvariant independent variables, as opposed to a fixed effects (FE) model. ${ }^{20}$ The RE model also adjusts standard errors amongst the multiple observations for each unit, which is important to reduce bias. To the point, the models that test $\mathrm{H} 1$ and $\mathrm{H} 3$ are run on the full sample, and the model that tests the mechanisms $(\mathrm{H} 2)$ is run on the sample of countries that eventually became members of the EU. It thereby excludes those that never acceded. ${ }^{21}$

In terms of short-comings, there might be a sample bias due to missing values for some countries, but not for others. The reason for these missing values is systematic in that

\footnotetext{
${ }^{20}$ A J test supported the inclusion of time-invariant factors. It is used to test overidentifying restrictions in a model, as well as to compare FE to RE for standard panel data estimation (see Sargan, 1958).

${ }^{21}$ It only makes sense to uncover mechanisms for treated units (i.e., those affected by EU integration).
} 
countries with varying levels of democratic experience have less available data. Nevertheless, aside from keeping this in mind, it should not represent a problem in terms of biased results. Decentralization is only genuine in democracies, thus making long un-democratic periods negligible (Brancati 2008). Additionally, we include full longitudinal data from more than half of the overall cases, as well as at least twelve years of pre-accession data from Central and Eastern European countries, which we consider plenty.

A second short-coming is that even though the fractionalization index is a good proxy for heterogeneity, it does not consider the geographic dispersal or concentration of ethnic, linguistic, and religious groups. Heterogeneity, however, is likely to only affect decentralization when the minorities are geographically concentrated. Nevertheless, the measure of party system nationalization taps into a similar social phenomenon and should at least partly capture geographically-concentrated groups. Additionally, it is only a control variable. A third short-coming is that we focus on the first year where the Regional Authority Index provides data, and it may be that each country's first year varies. As a result, it may over or under-estimate the real effect of the variable. And finally, we admit a certain level of weakness in the operationalization of the two mechanisms, as they could perhaps be confounded by unobserved factors. However, we made a decision to include them in the analysis as part of the first attempt to obtain useful insights on the matter.

\section{Results}

H1 explores the effect of EU integration on regional power. Table 1 presents the results from the random effects analysis. As discussed, Model 1 includes EU membership as the key independent variable, and Model 2 includes World Bank membership as a placebo test. 
Evidently, the direction of all effects is as hypothesized, and our variable of interest is highly statistically significant at the $.01 \%$ level. We can therefore infer that the longer a country is a member of the EU, the more decentralized it becomes; and that, after accession, subnational units become more powerful over the years. Specifically, for every membership year, the Regional Authority Index increases by an average of .127. The non-significance of the squared term of the independent variable ${ }^{22}$ also suggests that the effect of EU membership on regional authority is linear, which goes against our expectations.

Table 1 Here

Note: Bs are unstandardized coefficients from random effects multi-level models with robust standard errors (displayed in parenthesis in SE). ${ }^{*} p<0.05, * *<0.01, * * * p<0.001$.

Moreover, the effect of ethnic, linguistic, and religious fractionalization is in the expected direction but is not statistically significant. Perhaps because the variables are only heterogeneity proxies and do not capture geographic concentration. Party system nationalization, however, which taps into a similar concept, is significant at the $1 \%$ level. This is in line with the literature, which suggests that highly nationalized party systems decrease decentralization. Democracy is also positive and statistically significant. It means that, on average, higher democratic levels lead to a higher decentralization of power. Moreover, the control for GDP per capita is significant but has no sizeable effect (which

\footnotetext{
${ }^{22}$ Not displayed, but available upon request.
} 
should warrant further study). And finally, the controls for population and area size are in the expected direction and highly statistically significant, in line with the conventional wisdom that larger and more populated countries tend to be more decentralized.

Model 2 uses World Bank membership as a placebo test. As expected, the variable is positively correlated with decentralization and is highly statistically significant. Its funding and lending practices to economically-weak countries do seem to have a decentralizing effect. In this model, EU membership has a slight increase, which suggests that its effect on decentralization is not spurious; that it is not due to a general decentralization trend; and that it is not due to the mere presence of an international organization. A comparison between the magnitude of their effects ${ }^{23}$ also reveals that the impact of EU membership is almost five times higher than the impact of World Bank membership.

As for the mechanisms that link EU integration to the decentralization of regional power (H2), Table 2 includes the basic model, as well as one for each hypothesized mechanism (i.e., the subsidiarity principle, and the Commission's requirement to create regional governmental structures). The basic model (i.e., Model 3) reveals that the significance and direction of the key independent variable is unaffected by the reduced sample size ${ }^{24}$; and that, except for party system nationalization and surface area, the effects of the control variables remain stable. Model 4 illuminates the mechanisms that link EU integration and regional power. The coefficient for the subsidiarity principle is positive and

\footnotetext{
${ }^{23}$ We may compare the magnitude of their effects because they are both operationalized in years.

${ }^{24}$ As mentioned in earlier, this model is not run with the full sample. Only on EU member states.
} 
highly significant at the $.1 \%$ level, and it decreases the coefficient of the key explanatory variable, suggesting an important impact on regional power.

Table 2 - Here

Note: Bs are unstandardized coefficients from random effects multi-level models with robust standard errors (SE). * $p<0.05, * *<0.01, * * * p<0.001$.

Results from Model 5, on the other hand, go against our expectations. The variable for the requirement for accession candidates to create regional structures is negative and only significant at the $5 \%$ level. This could be due to the relative weakness of the operationalization, but there are reasons to be cautious before discarding it altogether. For example, the variable is somewhat constrained in time and may only be capturing transitory, short-term effects. The results may also reflect a baseline bias caused by characteristics that are unique to Eastern European countries ${ }^{25}$, including the possibility that the smaller, more centralized Eastern European states would have had a lower potential for decentralization anyway. In a similar vein, the results may also support Keating's (2008) claim that the EU turned into a 'force for centralization' after 2000; as well as the argument that these enlargements sometimes had centralizing effects (see Tatham 2014; Loughlin and Antunes 2019; and Saarts 2019).

\footnotetext{
${ }^{25}$ In terms of nationality politics, national minorities in Western Europe tend to seek more autonomy from their states (e.g., Catalonia, Scotland, Flanders, or Bavaria), whereas those in Eastern Europe tend to deal more with irredentism (e.g., Serbians in Croatia, or Russians in Estonia) (see Keating, 2008).
} 
The final two models pertain to $\mathrm{H} 3$, which challenges state-centric arguments and expects both self-rule and shared rule to increase with EU integration. Table 3 contains the two models with the different dependent variables. Specifically, Model 6 displays the impact of EU integration on self-rule, while Model 7 displays its impact on shared rule. As hypothesized, the length of EU membership increases both. The impact on self-rule, however, is much larger than on shared rule. This is consistent with evidence that shows that self-rule tends to interact substantially more with the process of EU integration than does shared rule (see Tatham and Bauer 2014; Tatham and Thau 2014; and López and Tatham 2018). This makes sense, given that self-rule is about autonomy, which is bound to be more affected by competence transfers to the EU than shared rule. In all, these results give additional strength to the multi-level argument (over the state-centrist argument). ${ }^{26}$

Table 3 here

Note: Bs are unstandardized coefficients from random effects multi-level models with robust standard errors (SE). ${ }^{*} p<0.05, * *<0.01, * * * p<0.001$.

\section{Conclusion}

${ }^{26}$ Standard diagnostics reveal that multicollinearity was never an issue, as VIF levels are all between 0.04 and $1.85($ Mean VIF $=1.41)$. 
This paper dealt with the long-debated question of the extent to which EU integration affects regional power. Until now, evidence for the two main existing theories (i.e., the multi-level and the state-centric governance models) had been mostly qualitative in nature, and ultimately inconclusive. The quantitative evidence from our study can thereby tilt the balance towards the multi-level governance theory and strengthen the external validity of previous findings. Moreover, as it included the first attempt at uncovering the causal mechanisms that link EU integration to regional power, it presents the field with a path for future relevant research.

In all, there were seven different models. The first two supported H1, as results showed that EU integration does lead to an increase in regional power over time. The following three models partly supported $\mathrm{H} 2$, as there was a statistically significant impact from the subsidiarity principle, but none from the Commission's requirement for accession candidates to create regional governance structures. As mentioned earlier, results for the latter may well support part of the literature (see Keating 2008; Bauer and Börzel 2010), but we argue that an important issue was that the indicator was only binary, and was possibly biased by collinearity and/or a possible misspecification of the time frame. Improving this aspect could be a positive future addition.

The final two models supported $\mathrm{H} 3$, as results showed that the length of EU membership increases both self-rule and shared rule (even if the impact on self-rule is significantly higher than on shared rule). In other words, they offered support for the multilevel governance theory and contradict the state-centric governance theory - as did the other models. From the results, we can conclude that regions are, in fact, 'winners' in the EU integration process (Dieringer and Sturm 2010). 
To be clear, however, the above does not mean that the nation-state is weak, or that the state-centric theory can be discarded altogether. The state-centric theory, for example, focuses purely on intra-state competences, and not on regional involvement at the supranational level. In other words, our study shows that regions gained considerable competences during the process of EU integration, but it does not address whatever competences may have been gained by nation-states or supra-national institutions. We do not look at how regional power compares to that of the two other levels. We also do not know if there is a trade-off, because power is not a zero-sum game. These might be opportunities for future research. Other future studies could quantitatively measure regions' extra-state influence; extend the time frame beyond 2010 to include recent developments; compare regional and national power to see how nation-states were affected by EU integration; use regional (instead of national) scores to deal with countries that only partly decentralize; or seek to highlight the conditions under which regions are more (or less) successful at using the 'momentum' of the

\section{AKNOWLEDGEMENTS}

We would like to thank Javier Astudillo for his guidance throughout this process, as well as the reviewers for their helpful comments and suggestions. 


\section{References}

Alesina, A., Angeloni, I. and Schuknecht, L. 2005. What does the European Union do?. Public Choice, 123: 275-319.

Alesina, A. et al. 2003. Fractionalization. Journal of Economic Growth 43(3):155-194.

Amat, F., Jurado, I. and León, S. 2009. A Political Theory of Decentralization Dynamics (Working Paper). Centro de Estudios Avanzados en Ciencias Sociales.

Amin, A. and Tomaney, J. 1995. The Regional Dilemma in a Neo-Liberal Europe. European Urban and Regional Studies, 2(2):171-188.

Bahl, R. and Nath, S. 1986. Public Expenditure Decentralization in Developing Countries. Environment and Planning C: Politics and Space 4(4):405-418.

Bauer, M. W. and Börzel T. A., 2010. Regions and the European Union. In: Enderlein, H.; Wälti, S.; Zürn, M. Handbook on Multilevel Governance. Cheltenham: Edward Elgar Publishers, pp. 253-263.

Besley, T. and Coate, S. 2003. Centralized versus Decentralized Provision of Local Public Goods: A Political Economy Approach. Journal of Public Economics 87(12): 2611-2637.

Beyers, J. and Donas, T. 2014. Inter-regional networks in Brussels: Analyzing the Information Exchanges among Regional Offices. European Union Politics 15(4): 547-571.

Bird, R. M. and Vaillancourt, F. 1999. Fiscal Decentralization in Developing Countries. Cambridge: Cambridge University Press.

Bochsler, D. 2010. Measuring party nationalisation: A new Gini-based indicator that corrects for the. Electoral Studies 29(1): 155-168.

Bookman, M. Z. 1993. The Economics of Secession. New York: St. Martin's Press.

Bourne, A. K., 2003. The Impact of European Integration on Regional Power. Journal of Common Market Studies 41(4):597-620.

Brancati, D. 2006. Decentralization: Fueling the Fire or Dampening the Flames of Ethnic Conflict and Secessionism?. International Organization 60(3): 651-685.

Brancati, D. 2008. The Origins and Strengths of Regional Parties. British Journal of Political Science 38(1): 135-159.

Brosio, G. 2012. Decentralization and Reform in Latin America: Improving Intergovernmental Relations. Northampton: Economic Commission for Latin America and the Caribbean.

Brusis, M. 2002. Between EU Requirements, Competitive Politics, and National Traditions: Recreating Regions in the Accession Countries of Central and Eastern Europe. Governance 15(4): 531559 . 
Bullmann, U. 1997. The Politics of the Third Level. In: Jeffery, C. The Regional Dimension of the European Union: Towards a Third Level in Europe?. London: Frank Cass, pp. 3-19.

Caporaso, J. and Keeler, J. 1993. The European Community and Regional Integration Theory. Washington, D.C., European Community Studies Association.

Chacha, M. 2020. European Union Membership Status and Decentralization: A Top-down Approach. Regional \& Federal Studies 30(1): 1-23.

Dieringer, J. 2010. Regionen und Regionalismus im Europäischen Kontext. In: Dieringer, J.; Sturm, R. Regional governance in EU-Staaten. Opladen: Barbara Budrich, pp. 347-363.

Dieringer, J. and Sturm, R. 2010. Regional Governance in EU-Staaten. Opladen: Barbara Budrich.

Elazar, D. J. 1987. Exploring Federalism. Tuscaloosa: University of Alabama Press.

Elias, A., 2008. Introduction; Whatever Happened to the Europe of the Regions? Revisiting the Regional Dimension of European Politics. Regional \& Federal Studies 18(5): 483-492.

EUR-Lex, 2012. Consolidated version of the Treaty on European Union, s.1.: Official Journal of the European Union.

Garret, G. and Weingast, B. 1991. Ideas, Interests, and Institutions: Constructing the European Community's Internal Market. In: Goldstein, J.; Keohane, R. Ideas and Foreign Policy: Beliefs, Institutions, and Political Change. Ithaca: Cornell University Press, pp. 173-203.

Garrett, G. 1992. International Cooperation and Institutional Choice: The EC's Internal Market. International Organizations, 46(2): 533-560.

Harvie, C. 1994. The Rise of Regional Europe. London: Routledge.

Hiscox, M. J. 2003. Political Integration and Disintegration in the Global Economy. In Kahler, M.; Lake, D. A.: Governance in a Global Economy: Political Authority in Transition. Princeton: Princeton University Press, pp. 60-86.

Hoffmann, S. 1966. Obstinate or Obsolete? The Fate of the Nation State and the Case of Western Europe. Daedalus 95(3): 892-908.

Hoffmann, S., 1982. Reflections on the Nation-State in Western Europe Today. Journal of Common Market Studies 21(1): 21-37.

Holesch, A. 2017. Bargaining for Self-Determination: The Secession Game in the EU. [Online] Available at: https://ecpr.eu/Filestore/PaperProposal/890a3106-292b-4c52-85cb-3400119beed9.pdf

Hooghe, L. and Keating, M. 1994. The politics of European Union regional policy. Journal of European Public Policy 1(3): 367-393.

Hooghe, L. and Marks, G. 2001. Multi-level Governance and European Integration. Lanham: Rowman \& Littlefield. 
Hooghe, L. et al. 2016. Community and the Structure of Governance. In: Hooghe, L.; Marks, G.; Schakel, A.; Chapman Osterkatz, S.; Niedzwiecki, S.; Shair-Rosenfield, S. Community, Scale, and Regional Governance: A Postfunctionalist Theory of Governance. Oxford: Oxford University Press, pp. 122-147.

Hooghe, L. et al. 2016. Measuring Regional Authority: A Postfunctionalist Theory of Governance. Oxford: Oxford University Press.

Hooghe, L., Marks, G. and Shakel, A. H. 2010. The rise of regional authority: A comparative study of 42 democracies. London: Routledge.

Huwyler, O., Tatham, M. and Blatter, J. 2018. Party politics, institutions, and identity: the dynamics of regional venue shopping in the EU. West European Politics 41(3): 754-778.

Jeffery, C. 1997. The Regional Dimension of the European Union: Towards a Third Level in Europe. London: Routledge.

Jeffery, C. 2000. Sub-National Mobilization and European Integration: Does it Make any Difference?. Journal of Common Market Studies 38(1): 1-23.

Jolly, S. K., 2015. The European Union and the Rise of Regionalist Parties. Ann Arbor: University of Michigan Press.

Jones, M. P. and Mainwaring, S. 2003. The Nationalization of Parties and Party Systems: An Empirical Measure and an Application to the Americas. Party Politics 9(2): 139-166.

Jordana, J., 2001. Relaciones Intergubernamentales y Descentralización en América Latina: Una Perspectiva Institucional. Inter-American Development Bank.

Kahler, M. and Lake, D. A. 2003. Globalization and Changing Patterns of Political Authority. In: Kahler, M.; Lake, D. A. Governance in a Global Economy: Political Authority in Transition. Princeton: Princeton University Press, pp. 412-438.

Keating, M. 1993. Regionalismo, Autonomía y Regímenes Internacionales. Barcelona: Institut de Ciències Polítiques i Socials.

Keating, M. 1998. Is there a Regional Level of Government in Europe?. In Lequesne, C.; Le Galès, P. Regions in Europe. London: Routledge, pp. 11-29.

Keating, M. 2004. Regions and Regionalism in Europe. Northampton: Edward Elgar.

Keating, M. 2008. Thirty Years of Territorial Politics. West European Politics, 31(1-2): 60-81.

Keating, M., Hooghe, L. and Tatham, M. 2015. Bypassing the nation-state? Regions and the EU policy process. In Richardson, J.; Mazey, S. European Union: Power and policy-making. Abingdon: Routledge, pp. 269-286.

Kohler-Koch, B. 1998. The Evolution and Transformation of European Governance (Reihe Politikwissenschaft), Vienna: Institut für Höhere Studien. 
La Cruz, R., Pineda, C. and Pöschl, C. 2010. La Alternativa Local: Descentralización y Desarrollo Económico. Washington, DC: Inter-American Developing Bank.

Letelier, L., 2016. Explaining Fiscal Decentralization. Public Finance Review, 33(2), pp. 155-183.

Litvack, J., Ahmad, J. and Bird, R. 1999. Rethinking decentralization in developing countries. Washington, DC: World Bank.

López, F. and Tatham, M. 2018. Regionalisation with Europeanisation? The Rescaling of Interest Groups in Multi-Level Systems. Journal of European Public Policy 25(5): 764-786.

Loughlin, J. 1997. Representing Regions in Europe: The Committee of the Regions. In Jeffery, C. The Regional Dimension of the European Union: Towards a Third Level in Europe?. London: Frank Cass, pp. 147-165.

Loughlin, J. and Antunes, S. 2019. State rescaling and a 'Europe of the Regions' in small unitary states: A damp squib?. Regional \& Federal Studies 30(2): pp. 1-19.

Margedant, U. 2006. Regionen in Europa. In Zimmermann-Steinhart, P. Regionale Wege in Europa: Föderalismus, Devolution, Dezentralisierung. Munich: Allitera Verl, pp. 162-168.

Marks, G. 1993. Structural policy and multi-level governance in the EC. In Cafruny, A.; Rosenthal, G.: The State of the European Community: The Maastricht Debate and Beyond. Boulder(CO): Lynne Rienner, pp. 391-441.

Marks, G. and Hooghe, L. 2004. Contrasting visions of multi-level governance. In Bache, I.; Flinders, M. Multi-Level Governance. Oxford: Oxford University Press, pp. 15-30.

Marks, G., Hooghe, L. and Blank, K. 1996. European Integration from the 1980s: State-Centric v. Multi-level Governance. Journal of Common Market Studie, 34(3): 341-378.

Marshall, M. G., Gurr, T. R. and Jaggers, K. 2018. Polity IV Project: Political Regime Characteristics and Transitions, 1800-2017. Dataset Users' Manual, Vienna: Center for Systemic Peace.

McCormick, J. 1999. The European Union: Politics and Policies. Boulder: Westview Press.

Milward, A. 1992. The European Rescue of the Nation-State. Berkeley: University of California Press.

Moravcsik, A. 1991. Negotiating the Single European Act: National Interests and Convnetional Statecraft in the European Community. International Organization 45(1): 651-688.

Moravcsik, A. 1993. Preferences and Power in the European Community: A Liberal Intergovernmental Approach. Journal of Common Market Studies 31(4): 473-524.

Nagel, K.-J. 2009. Zur Europapolitik und Europafähigkeit der Spanischen Regionen. In Lambertz, K.-H.; Große-Hüttmann, M. Schriftenreihe des Europäischen Zentrums für Fëderalismus-Forschung. Tübingen: Europäischen Zentrums für Föderalismus-Forschung Tübingen, p. 84-100. 
Nagel, K.-J, 2010. Spanien-Auf dem Weg zur Föderation?. In Dieringer, J.; Sturm, R. Regional Governance in EU-Staaten. Opladen: Barbara Budrich, pp. 149-172.

Neshkova, M. I. 2010. The impact of subnational interests on supranational regulation. Journal of European Public Policy 17(8):1193-1211.

Oates, W. 1972. Fiscal Federalism. New York City: Harcourt Brace Jovanovich.

Panizza, U. 1999. On the Determinants of Fiscal Centralization: Theory and Evidence. Journal of Public Economics 74(1): 97-139.

Rokkan, S. and Urwin, D. W., 1982. The Politics of Territorial Identity: Studies in European Regionalism. London: Sage Publications.

Saarts, T. 2019. Introducing regional self-governments in Central and Eastern Europe: Paths to success and failure. Regional \& Federal Studies: 1-25.

Sargan, J. 1958. The Estimation of Economic Relationships Using Instrumental Variables. Econometrica 26(3):393-415.

Schakel, A. H. 2009. A Postfunctionalist Theory of Regional Government: An Inquiry into Regional Authority and Regional Policy Provision. Veenendaal: Universal Press.

Shah, A. 2004. Fiscal Decentralization in Developing and Transition Economies: Progress, Problems, and the Promise, Washington: World Bank.

Sharpe, L. 1993. The Rise of the Meso Government in Europe. London: SAGE Publications.

Stegarescu, D. 2009. The Effects of Economic and Political Integration on Fiscal Decentralization: Evidence from OECD Countries. The Canadian Journal of Economics 42(2): 694-718.

Stephenson, P. 2013. Twenty years of multi-level governance: 'Where Does It Come From? What Is It? Where Is It Going?’ Journal of European Public Policy 20(6): 817-837.

Storper, M, 1995. The Resurgence of Regional Economies, Ten Years Later: The Region as a Nexus of Untraded Interdependencies. European Urban and Regional Studies 2(3): 1991-221.

Streeck, W. 1996. Neo-Voluntarism: A New European Social Policy Regime?. In Marks, G.; Scharpf, S.; Schmitter, P.C.; Streeck, W. Governance in the Emerging Euro-Polity. London: Sage.

Sturm, R. 2009. Die 'Europafähigkeit' der Regionen. In Lambertz, K.-H.; Große-Hüttmann, M.: Europapolitik und Europafähigkeit von Regionen. Tübingen: Europäischen Zentrums für Föderalismus-Forschung Tübingen, pp. 11-20.

Sturm, R. and Bauer, M. W., 2010. Governance und Regionen: Die Theoretische Debatte. In Dieringer, J.; Sturm, R.: Regional Governance in EU-Staaten. Opladen: Barbara Budrich, pp. 11-34.

Tatham, M. 2008. Going solo: Direct regional representation in the European Union. Regional and Federal Studies, 18(5): 493-515. 
Tatham, M. 2010. 'With or without you'? Revisiting territorial state-bypassing in EU interest representation. Journal of European Public Policy 17(1): 76-99.

Tatham, M. 2014. Limited institutional change in an international organisation: accounting for the EU's shift away from 'federal blindness'. European Political Science Review 6(1): 21-45.

Tatham, M. 2015. Regional Voices in the European Union: Subnational Influence in Multilevel Politics. International Studies Quarterly 59(2): 387-400.

Tatham, M. 2018. The Rise of Regional Influence in the EU - From Soft Policy Lobbying to Hard Vetoing. Journal of Common Market Studies 56(3): 672-686.

Tatham, M. and Bauer, M. W. 2014. Competence ring-fencing from below? The drivers of regional demands for control over upwards dispersion. Journal of European Public Policy 21(9): 1367-1385.

Tatham, M. and Thau, M. 2014. The More the Merrier: Accounting for regional paradiplomats in Brussels. European Union Politics 15(2): 255-276.

Taylor, P. 1983. The limits of European integration. New York: Columbia University Press.

Urwin, D. W. 1998. Modern Democratic Experiences of Territorial Management: Single Houses, but Many Mansions. Regional and Federal Studies 8(2): 81-110.

Van Houten, P. 2003. Globalization and Demands for Regional Autonomy in Europe. In Kahler, M.; Lake, D.A.: Governance in a Global Economy: Political Authority in Transition. Princeton: Princeton University Press, pp. 110-135.

Weyand, S. 1997. Inter-Regional Associations and the European Integration Process. In Jeffery, C.: The Regional Dimension of the European Union: Towards a third level in Europe. London: Frank Cass, pp. 166-182.

Willis, E., Garman, C. d. C. B. and Haggard, S. 1999. The Politics of Decentralization in Latin America. Latin American Research Review 34(1): 7-56.

World Bank, 2004. Devolution in Pakistan: An Assessment \& Recommendations for Action, Washington: World Bank.

World Bank, 2018. Member Countries. [Online] Available at: http://www.worldbank.org/en/about/leadership/members

World Bank, 2019. Member Countries. [Online] Available at: https://data.worldbank.org/indicator/NY.GDP.PCAP.CD

Wu, A. and Want, W. 2013. Determinants of Expenditure Decentralization: Evidence from China. World Development:176-184. 